\title{
Changes in Morphology of Alveolar Buccal Walls Following Atraumatic Internal Root Fragmentation
}

\author{
Cambios en la Morfología de las Paredes Alveolares Bucales \\ Después de Fragmentación Radicular Interna Atraumática
}

Wilfried Engelke"; Víctor Beltrán ${ }^{* * * *}$; Oscar Decco ${ }^{* * *}$; Iván Valdivia-Gandur ${ }^{* * * * *}$; Pablo Navarro** \& Ramón Fuentes ${ }^{* * *}$

ENGELKE, W.; BELTRÁN, V.; DECCO, O.; VALDIVIA-GANDUR, I.; NAVARRO, P. \& FUENTES, R. Changes in morphology of alveolar buccal walls following atraumatic internal root fragmentation. Int. J. Morphol., 33(2):491-496, 2015.

SUMMARY: The buccal alveolar wall represents the most important structure to provide shape and volume of the alveolous following tooth extraction. The aim of the study was the evaluation of buccal alveolar bone structures following minimally invasive surgery. In 15 patients ( 3 male, 12 female), aged 20-67 years, 3 central incisors, 5 lateral incisors, and 7 bicuspids were removed using flapless enucleation. The enucleation comprised endoscopically assisted mesiodistal root sectioning with inward fragmentation of the oral and apical parts followed by internal reduction of the buccal root lamella. Buccal bone height before extraction was $10.61 \mathrm{~mm}$, following extraction $10.50 \mathrm{~mm}$. Crestal width of the buccal bone plate was $1.11 \mathrm{~mm}$ before and $1.40 \mathrm{~mm}$ after tooth removal. Apical buccal bone width before was $0.66 \mathrm{~mm}$ and after extraction $0.40 \mathrm{~mm}$. Gingival height was $13.58 \mathrm{~mm}$ before and $13.56 \mathrm{~mm}$ following extraction. Following transalveolar enucleation, the buccal alveolar bone wall remains unchanged concerning height and crestal width.

KEY WORDS: Extraction socket; Buccal plate; Endoscopes; Microsurgical removal; Enucleation.

\section{INTRODUCTION}

Ankylosis is a major problem in oral surgery. It may develop following dental trauma to the root surface resulting in bone contact with the root surface without an intermediate attachment apparatus (Fuss et al., 2003). Ankylosis develops as consequence of periodontal trauma, if the periodontal ligament is replaced by bone tissue, or as a consequence of endodontic treatment which usually is carried out following a pulpal infection with subsequent loss of vital dentine (Fuss et al.). Following ankylosis, resorption of cementum and root dentin occurs. These processes eventually result in replacement of the entire root by bone (Levin et al., 2004).

In the developing dentition, aggressive surgical removal of an ankylosed deciduous tooth may cause damage to the developing crown of the successor (Kirshenblatt \& Kulkarni, 2011). In the permanent dentition the surgical extraction of an ankylosed tooth implies buccal osteotomy and often leads to considerable bone loss and reduced bone volume in the oro-facial dimensión (Filippi et al., 2001). Thus the loss of buccal bone may increase the loss of facial soft tissues and gingival recessions following implant placement (Caiazzo et al., 2013). Although some modern devices for extraction have been introduced (Muska et al., 2012) allowing for atraumatic extraction in $83 \%$ of cases, there is still a significant number of $17 \%$ of teeth, which cannot be extracted atraumatically and in turn require open surgical extraction.

As an alternative, the transalveolar flapless approach for tooth removal generally can provide favorable conditions to avoid buccal alveolar bone defects, which are generated during open surgical extraction. Flapless approaches to partially erupted mandibular third molars were described and evaluated by Kim et al. (2011) exhibiting low postoperative morbidity. In a recent publication on the occlusal miniflap approach with inward fragmentation of

* Department of Oral and Maxillofacial Surgery (Head: Prof. Dr. Dr. Henning Schliephake), Georg-August-Universität, Göttingen, Germany.

** Faculty of Dentistry, CIMOFIR Research Center, Universidad de La Frontera, Temuco, Chile.

**** Department of Bioengineering, Faculty of Engineering, Universidad Nacional de Entre Rios, Argentina

${ }^{* * * *}$ Anatomy Unit, Biomedical Department and Department of Dentistry, Universidad de Antofagasta, Antofagasta, Chile.

This study was predominantly supported by the Faculty of Dentistry, Universidad de La Frontera, Temuco, Chile and Georg-August-University Göttingen, Germany. Also in part by a research grant of Degradable Solutions AG, Schlieren, Switzerland and MEC Project of the National Commission for Scientific and Technological Research - CONICYT, Chile. This study was registred and approved as research project (DI12-PE08) at the Universidad de La Frontera, Temuco, Chile. 
impacted mandibular third molars, maintenance of more than $90 \%$ of buccal bone height was reported (Engelke et al., 2014). Most recently, a microsurgical technique was described to remove ankylosed roots in the aesthetic zone using endoscopically assisted root sectioning (Engelke et al., 2012).

A recent review confirmed that flapless approaches provide some important advantages as minimized trauma to the soft tissue, reduced scar formation, preservation of osseous vascularization via the periosteum and reduced patient discomfort (Doan et al., 2012).

The present report was designed to provide more objective quantitative data on the use of the flapless enucleation during endoscopically assisted sectioning of ankylosed anterior maxillary roots, where open surgical extraction is critical and the maintenance of the alveolar frame structure is most important for an aesthetic outcome.

\section{MATERIAL AND METHOD}

Patient selection. The present investigation was conducted at the Dept. of Maxillofacial Surgery, Universitätsmedizin Göttingen (UMG) of Georg-August-Universität, Göttingen, Germany and the Faculty of Dentistry of the Universidad de La Frontera (UFRO), Chile.

All patients were systemically healthy, not pregnant, and non-smokers. In 15 patients ( 3 male, 12 female), aged 20-67 years, 3 central incisors, 5 lateral incisor and 7 bicuspids were removed. Inclusion criteria were ankylosed anterior maxillary teeth with given indication for extraction. Presurgical evaluation comprised clinical examination and CBCT scan. Ankylosis was diagnosed, if a grade 0 mobility was assessed and the continuity of the buccal periodontal gap was interrupted at least for $3 \mathrm{~mm}$. After the initial periodontal therapy, the surgical operations were started.

Ethical approval was granted by the ethical committee of the Medical Faculty of UMG (registration No. 12/9/10) and the ethical committee of the Faculty of UFRO (registration No. 246/006). All subjects were asked to provide an informed consent to participate after a detailed explanation of the procedures and objectives of the study.

Surgical procedure. Flapless enucleation (Engelke et al., 2014) was performed under local anesthesia. On a preoperative CBCT (Fig. 1A) the zone of ankylosis was identified. To obtain a precise view of the root cross section, the crown was removed completely at the level of the gingiva and a mesiodistal sectioning (MDS) of the cervical half of the root was carried out (Fig. 2). The oral part of the root was removed by further sectioning and inward fragmentation. The buccal lamella was then separated from the apical part of the root with preservation of its coronal third in contact with the buccal bone plate. After inward fragmentation and removal of the apex under direct vision, the ankylosed root lamella was reduced to a thickness below $1 \mathrm{~mm}$ at the marginal bone level and served as reinforcement of the buccal alveolar bone wall.

Evaluation. Measurement of alveolar structures was performed prior to surgery and during surgery after removal of the root. Preoperative measurements were made on a CBCT taken within 3 weeks before surgery (Fig. 1A-B). An orovestibular reconstruction along the long axis of the tooth was used, the reading accuracy was set to $0.2 \mathrm{~mm}$, two independent examiners performed the measurements, the mean value of both examiners were used for further calculations. Intraoperative examination was performed under direct view with the support endoscope using an alveolometer, designed for this study by the authors Engelke \& Beltrán (Fremiq Sur®, Temuco, Chile) (Fig. 3). The alveolometer is a graduated caliper like instrument with one straight graduated branch to be placed internally along the alveolar wall and a rectangulated branch with a sharp end. The latter is placed on the external bone surface (Fig. 3A-C). The distance between the endpoints of both branches allowed assessment of the bone width, a graduated scale on the branch allowed length measurement, both with a reading accuracy of $0.5 \mathrm{~mm}$. All measurements were performed by two examiners, the mean values were taken for further calculations.

Measurement sites are shown in Figure 4A-B. The most apical point of the alveolous (A) served as reference. The distance of $\mathrm{A}$ to the bone margin (BM) was taken as buccal bone height $(\mathrm{BBH})$. The distance of $\mathrm{A}$ to the gingival margin (GM) was defined as buccal gingival height (GH). The width of the buccal bone plate was determined rectangular to the long axis of the tooth in the mid crestal third (crestal width, $\mathrm{CW}=\mathrm{CW}-\mathrm{CW}^{\prime}$ ) and the mid apical third of the alveolous (apical width, AW = AW-AW').

Data analysis was performed using SPSS/PC version 20.0 sofware (SPSS Inc., Chicago, IL, USA). For all measurements, means and standard deviations were calculated. Pre and post extraction parameters were compared using the Mann-Whitney U Test, P -value was set to 0.05 .

As hypothesis of the study it was assumed that buccal bone height $(\mathrm{BBH})$, gingival height $(\mathrm{GH})$, crestal width $(\mathrm{CW})$ and apical width (AW) after tooth removal did not change as a result of surgery. 

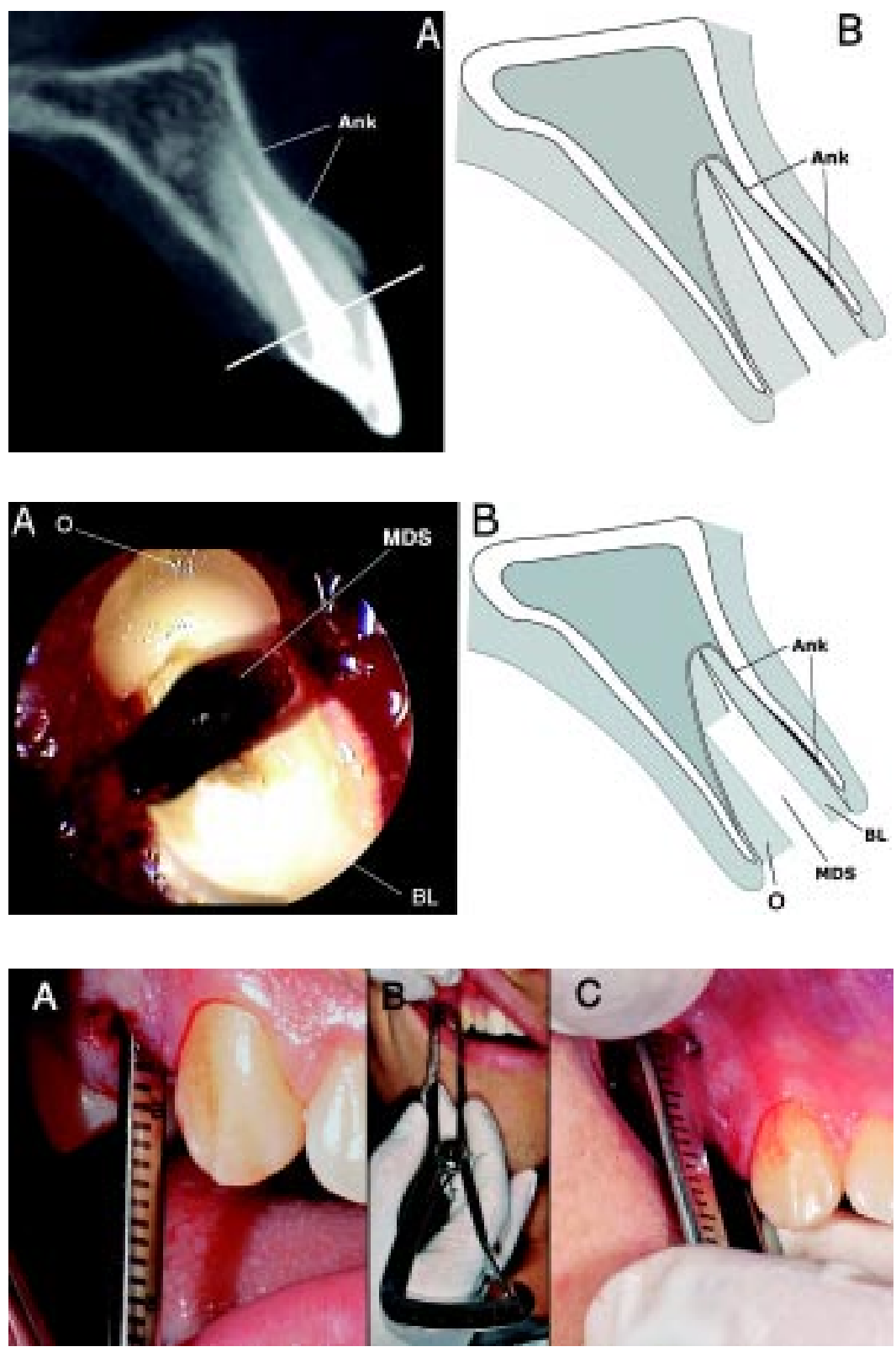

A

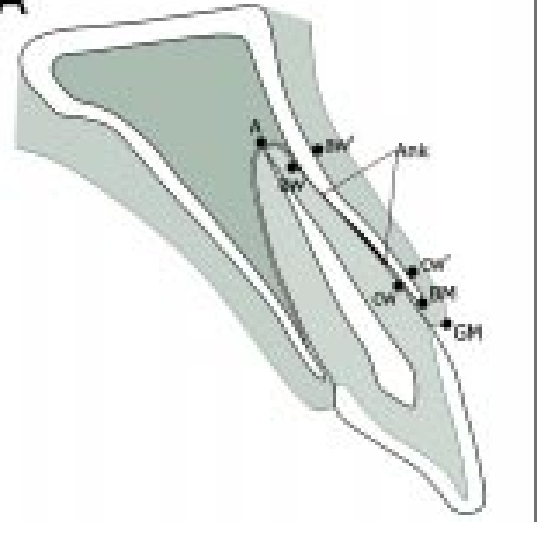

Fig. 1. A. Crossectional view of an ankylosed tooth in situ (CBCT); B. Schematic representation of the crown removal at gingival level. Ank= Zone of ankylosis.

Fig. 2. Mesiodistal sectioning (MSD) with formation of a buccal (BL) and oral $(\mathrm{O})$ root lamellae. A. Occlusal endoscopic view; B. Crossectional representation.

Fig. 3. Intraoperative evaluation following flapless enucleation. A. Measurement of vertical socket dimensions; B. Alveolometer in situ; C. Measurement of transverse socket dimensions. 


\section{RESULTS}

The results of measurements are summarized in Table I. The mean buccal bone height was $10.61 \mathrm{~mm}$ before and 10.50 after root removal. Gingival height was $13.58 \mathrm{~mm}$ before and $13.56 \mathrm{~mm}$ after root removal, the mean crestal width was $1.11 \mathrm{~mm}$ before, and $1.40 \mathrm{~mm}$ following root removal, the mean apical width was $0.66 \mathrm{~mm}$ before and $0.40 \mathrm{~mm}$ following root removal. The difference of apical width as a result of surgery was significant. As shown in Table II, a significant reduction of buccal wall thickness was confirmed only in AW. No significant change of BBH, GH and $\mathrm{CW}$ was found as a result of surgery.

Table I. Alveolar dimension measurements $(\mathrm{mm})$ before and after flapless enucleation: $\mathrm{BBH}=\mathrm{Buccal}$ bone height, $\mathrm{GH}=$ Gingival height, $\mathrm{CW}=$ Crestal width, $\mathrm{AW}=$ Apical width.

\begin{tabular}{lcccc}
\hline $\mathbf{n}=1 \mathbf{1 6}$ & Mean & Min & Max & SD \\
\hline BBH pre & 10.61 & 7.0 & 13.2 & 1.86 \\
BBH post & 10.50 & 7.5 & 13 & 1.61 \\
GH pre & 13.58 & 11.3 & 16.0 & 1.20 \\
GH post & 13.56 & 11.0 & 16.0 & 1.32 \\
CW pre & 1.11 & 0.3 & 2.2 & 0.55 \\
CW post & 1.40 & 0.5 & 2.0 & 0.38 \\
AW pre & 0.66 & 0 & 1.3 & 0.31 \\
AW post & 0.40 & 0 & 1.5 & 0.34 \\
\hline
\end{tabular}

Table II. Statistical evaluation (Mann Whitney Test) of measurements, (*) indicates a statistically significant difference.

\begin{tabular}{lc}
\hline $\begin{array}{l}\text { Preoperative vs. } \\
\text { postoperative dimension }\end{array}$ & p-value \\
\hline BBH & 0.368 \\
GH & 0.859 \\
CW & 0.115 \\
AW & $0.000^{*}$ \\
\hline
\end{tabular}

\section{DISCUSSION}

Ankylosis represents a typical clinical situation where alveolar ridge frame preservation is difficult to obtain. Conventional strategies of open surgical extraction always involve a reduction of the alveolar frame with negative consequences for later implant placement. Based on the observation, that in case of traumatic injury, a replacement resorption of resting roots occurs with maintenance of the alveolar shape (Filippi et al.), we assume that parts of the natural root may be used as stabilizing elements of the alveolar frame to improve the conditions of bone healing after tooth removal.
Davarpanah \& Szmukler-Moncler (2009) reported implant placement in contact with ankylosed root fragments without any specific pathological sign after a period of 12 42 months of loading in 5 cases. Hürzeler et al. (2010) concluded in a report on the socket shield technique: Retaining the buccal aspect of the root during implant placement does not appear to interfere with osseointegration and may be beneficial in preserving the buccal bone plate. For the purpose of exodontia the concept described in the present report implies that ankylosed parts of the root might be left in place in order to avoid biomechanical damage of the alveolar frame. Consequently, modern oral surgery should focus on the selective removal of those hard and soft tissue components which are a risk of infection, cause pain or do not fulfil functional or aesthetic tasks. In contrast, structures which protect the existing shape of the alveolus, provide nutrition of important structures, may serve temporarily as support elements and later undergo replacement resorption. Compared to conventional extraction procedures, the technique of endoscopically assisted root sectioning may protect the surrounding alveolus especially in the aesthetic zone similar to the reports of Yalcin et al. (2009), Al Harbi (2010) and Hürzeler et al.

Within the limitation of the measurement conditions, our results show, that a complete maintenance of the buccal plate can be achieved in the crestal zone. This refers to the vertical height as well as the crestal width of the buccal wall. The slight increase in width may be a result of the reinforcement by the root lamella. In conclusion, the marginal frame structure can be maintained without damage to the hard tissue and the soft tissue frame either.

In the apical zone, however a reduction of width can be observed. This indicates that the apical root removal still may result in some bone loss due to the close relationship of the roots to the delicate buccal walls. Additionally, the separation of the buccal lamella from the apical third may lead to local exposure of the periostium. However, bone healing away from the marginal zone may not result in major contour change compared to the inevitable reduction of the marginal alveolar bone during open surgery.

Some technical details appear to be important to obtain favorable results: Mesiodistal sectioning isolates the buccal root lamella and thus prevents damage to adjacent alveolar wall fragments. Inward fragmentation of the oral root segment opens the view to the apical alveolar space to obtain access to the anatomically critical apical root segment. Care is needed and precise endoscopic visualization not to perforate the underlying buccal bone plate during sectioning. However in case of extended zones of ankylosis, a circumscript exposure of the periosteum in the apical zone 
cannot be avoided. If the zone of ankylosis is located apically only, the resting coronal part of the root might show mobility following separation.

Using the inward fragmentation technique, various concepts of conservative extraction techniques may be supported, the published experience with third mandibular molars shows (Landi et al., 2010), that a shift of paradigms can be observed and the complete removal of roots may not be recommendable a tout prix.

The technique presented here is based on a procedure which already has been applied in retained third molars widely and generally opens a variety of options for the oral surgeon to conserve or completely remove root tissue in complex anatomical situations without raising flaps and without external osteotomy. Thus conditions are provided to preserve the anatomical integrity of the marginal alveolar frame whenever required.

\section{CONCLUSION}

Critical anatomical zones of the alveolar socket, including height and crestal width of the buccal bone wall can be preserved when removing of ankylosed roots with internal fragmentation.

ENGELKE, W.; BELTRÁN, V.; DECCO, O.; VALDIVIA-GANDUR, I.; NAVARRO, P. \& FUENTES, R. Cambios en la morfología de las paredes alveolares bucales después de fragmentación radicular interna atraumática. Int. J. Morphol., 33(2):491-496, 2015.

RESUMEN: La pared alveolar bucal representa la estructura más importante para proveer la forma y el volumen de los alveólos dentales posterior a la extracción dental. El objetivo del estudio fue evaluar las estructuras de hueso alveolar bucal después de la cirugía mínimamente invasiva. En 15 pacientes (3 hombres, 12 mujeres), con edades entre 20 a 67 años, 3 incisivos centrales, 5 incisivos laterales y 7 premolares fueron removidos utilizando enucleación sin colgajo. La enucleación comprende el seccionamiento mesio-distal de la raíz dental endoscópicamente asisitido a través de fragmentación interna de la porción lingual y apical radicular y posteriomente una reducción interna de la lamela de raíz bucal. La altura ósea bucal antes de la extracción fue 10,61 mm y después de la extracción fue $10,50 \mathrm{~mm}$. La anchura de la cresta ósea bucal fue 1,11 mm y 1,40 mm después de la extracción del diente. El grosor del hueso apical antes de la extracción fue 0,66 mm y 0,40 mm después de la extracción. La altura gingival fue 13,58 mm antes de la extracción y 13,56 mm después de la extracción. Después de la enucleación transalveolar, la pared del hueso alveolar bucal se mantiene sin cambios en relación con la altura y del grosor del reborde alveolar.

PALABRAS CLAVE: Alveolo de extracción; Pared bucal; Endoscopios; Remoción microquirúrgica; Enucleación.

\section{REFERENCES}

Al-Harbi, S. H. Minimizing trauma during tooth removal: a systematic sectioning approach. Eur. J. Esthet. Dent., 5(3):274$87,2010$.

Caiazzo, A.; Brugnami, F. \& Mehra, P. Buccal plate preservation with immediate post-extraction implant placement and provisionalization: preliminary results of a new technique. Int. J. Oral Maxillofac. Surg., 42(5):666-70, 2013.

Davarpahah, M. \& Szmukler-Moncler, S. Unconventional implant placement. 2: placement of implants through impacted teeth. Three case reports. Int. J. Periodontics Restorative Dent., 29(4):405-13, 2009.

Doan, N.; Du, Z.; Crawford, R.; Reher, P. \& Xiao, Y. Is flapless implant surgery a viable option in posterior maxilla? A review. Int. J. Oral Maxillofac. Surg., 41(9):1064-71, 2012.

Engelke, W.; Beltrán, V.; Fuentes, R. \& Deccó, O. Endoscopically Assisted Root Splitting (EARS): Method and First Results. Int. J. Odontostomat., 6(3):313-6, 2012.
Engelke, W.; Beltrán, V.; Cantín, M.; Choi, E. J.; Navarro, P. \& Fuentes, R. Removal of impacted mandibular third molars using an inward fragmentation technique (IFT) - Method and first results. J. Craniomaxillofac. Surg., 42(3):213-9, 2014.

Filippi, A.; Pohl, Y. \& von Arx, T. Decoronation of an ankylosed tooth for preservation of alveolar bone prior to implant placement. Dent. Traumatol., 17(2):93-5, 2001.

Fuss, Z.; Tsesis, I. \& Lin, S. Root resorption--diagnosis, classification and treatment choices based on stimulation factors. Dent. Traumatol., 19(4):175-82, 2003.

Hürzeler, M. B.; Zuhr, O.; Schupbach, P.; Rebele, S. F.; Emmanouilidis, N. \& Fickl, S. The socket-shield technique: a proof-of-principle report. J. Clin. Periodontol., 37(9):855-62, 2010 .

Kim, H. R.; Choi, B. H.; Engelke, W.; Serrano, D.; Xuan, F. \& Mo, D. Y. A comparative study on the extractions of partially impacted mandibular third molars with or without a buccal 
ENGELKE, W.; BELTRÁN, V.; DECCO, O.; VALDIVIA-GANDUR, I.; NAVARRO, P. \& FUENTES, R. Changes in morphology of alveolar buccal walls following atraumatic internal root fragmentation. Int. J. Morphol., 33(2):491-496, 2015

flap: a prospective study. J. Oral Maxillofac. Surg., 69(4):96670, 2011.

Kirshenblatt, S. \& Kulkarni, G. V. Complications of surgical extraction of ankylosed primary teeth and distal shoe space maintainers. J. Dent. Child. (Chic.), 78(1):57-61, 2011.

Landi, L.; Manicone, P. F.; Piccinelli, S.; Raia, A. \& Raia, R. A novel surgical approach to impacted mandibular third molars to reduce the risk of paresthesia: a case series. J. Oral Maxillofac. Surg., 68(5):969-74, 2010.

Levin, I.; Ashkenazi, M. \& Schwartz-Arad, D. Preservation of alveolar bone of un-restorable traumatized maxillary incisors for future. Refuat Hapeh Vehashinayim, 21(1):54-9, 101-2, 2004.

Muska, E.; Walter, C.; Knight, A.; Taneja, P.; Bulsara, Y.; Hahn, M.; Desai, M. \& Dietrich, T. Atraumatic vertical tooth extraction: a proof of principle clinical study of a novel system. Oral Surg. Oral Med. Oral Pathol. Oral Radiol., 116(5):e30310, 2013.

Yalcin, S.; Aktas, I.; Emes, Y.; Kaya, G.; Aybar, B. \& Atalay, B. A technique for atraumatic extraction of teeth before immediate implant placement using implant drills. Implant Dent., 18(6):464-72, 2009.

\author{
Correspondence to: \\ Prof. Dr. W. Engelke \\ Universitätsmedizin Göttingen \\ Abt. Mund-Kiefer-Gesichtschirurgie \\ Robert Koch Str. 40 \\ Göttingen \\ GERMANY
}

Tel. 49551398303

Email: wengelke@med.uni-goettingen.de

Received: 22-12-2014

Accepted: 17-03-2015 